\title{
6
}

\section{Unsung Heroes: Recreating the Ensemble Dynamic of Motown's Funk Brothers}

\author{
Vincent Perry
}

\section{Introduction}

By the early 1960s, the genre known as soul had become the most commercially successful of all the crossover styles. Drawing on musical influences from the genres of gospel, jazz and blues, 'soul's success was as much due to a number of labels, so-called "house sounds", and littleknown bands, as it was to specific performers or songwriters' (Borthwick and Moy, 2004, p. 5). Following on from the pioneer releases of Ray Charles and Sam Cooke, a Detroit-based independent label would soon become the 'most successful and high profile of all the soul labels' (Borthwick and Moy, 2004, p. 5).

Throughout the early 1960s, Berry Gordy's Tamla Motown dominated the domestic US pop and R\&B charts with its assembly-line approach to music production (Moorefield, 2005, p. 21), which resulted in a distinctive sound that was shared by all the label's artists. However, in 1963, the company 'achieved its international breakthrough' shortly after signing a landmark distribution deal with EMI in the UK (Borthwick and Moy, 2004, p. 5). Gordy's headquarters—a seemingly humble, suburban 
residence-was ambitiously named Hitsville USA and, throughout the 1960s, it became a hub for pop record success. Emerson (2005, p. 194) acknowledged Motown's industry presence when he noted:

Motown was muscling in on the market for dance music. Streamlined, turbo-charged singles by the Marvelettes, Martha and the Vandellas, and the Supremes rolled off the Detroit assembly line ... Berry Gordy's 'Sound of Young America' challenged the Brill Building, 1650 Broadway, and 711 Fifth Avenue as severely as the British Invasion because it proved that black artists did not need white writers to reach a broad pop audience.

Using a model established by Jerome 'Jerry' Leiber and Mike Stoller a few years earlier, Gordy entrusted both songwriting and production duties to a collection of specialised individuals and teams to create new recorded material. Further, this African-American entrepreneur saw the immense 'commercial potential in producing records that could cross over from the rhythm-and-blues charts onto the pop charts' (Covach and Flory, 2012 , p. 224), Gordy decided to produce and market his recordings to be 'acceptable to white listeners in their original versions', thus preventing covers of his songs by white artists - a strategy adopted from Chuck Berry (Covach and Flory, 2012, p. 224).

However, much of the stardom and financial return were shared by only a select few involved in the production processes. While the singers became household names and the songwriters prospered with royalty earnings, recording session instrumentalists remained largely unacknowledged. The collection of musicians in question was the Motown house band known as the Funk Brothers. Gordy recruited many of these men after they were discovered performing in various Detroit jazz lounges and clubs. From their basement recording space- affectionately called the Snake Pit - they were hired to record the rhythm section beds ${ }^{1}$ for songs that would soon take the US and the world by storm. According to scholarly literature, the Funk Brothers were central to Motown's early success. Lozito (2001, p. 86), pays homage to this house band and his respect for these instrumentalists is clear when he stated:

1 The Motown rhythm section beds would often consist of a drummer (sometimes two drummers on separate drum sets), electric/upright bassist, three electric guitarists, multiple keyboardists, a tambourine player and a mallet percussionist (predominantly vibraphone) (Justman, 2002). The collective task of the rhythm sections of this era was to establish a solid foundation for the singers, instrumental soloists and other members of the ensemble that focused on the melody (Covach and Flory, 2012, p. 17). 
There were many elements and individuals who combined to make Motown great, and there were none more so than the backing musicians. Together they were the rock on which the empire was built.

Their technical proficiency as session musicians became well known in recording circles. Covach and Flory (2012, p. 125) noted, 'these players were adept at creating their parts on the spot, often without the benefit of scored-out parts or even a completed formal design'. Based on the existing literature that investigates the operations and business ethics of Motown, it is evident that Gordy certainly 'knew the worth of his Detroit musicians' (George, 2003). However:

That didn't mean he paid them top dollar until he had to, and it didn't mean he felt they should be stars. None of Motown's albums carried the musicians' credits until the seventies. The musicians were never cited by name in interviews with artists, producers, or executives during the sixties. (p. 119)

As a popular music scholar, I was also relatively unaware of the contributions of the Funk Brothers. Further, I have often wondered, 'What exact factors contributed to the Motown backing band's success?'. Was it simply just musicianship and camaraderie among the ensemble that influenced Motown's iconic records? Did the audio engineering limitations ${ }^{2}$ of 1960 s recording technology demand and promote better time efficiency and musical performances? Did the small confines of Motown's basement recording room provide the band with the ideal environment to record as an ensemble? And, lastly, why weren't these instrumentalists properly credited for their musical contributions?

To answer these questions, I proposed a recording/research project to investigate the Funk Brother's formula for success. As a music practitioner and academic, I proposed an ethnographic and practice-led research project. I assembled a collection of Brisbane-based musicians (informally referred to as the Brisbane Jam Fam) and asked them to collaborate with me to compose, record, arrange and produce a new album called Soul Sundays, which would consist of 10 Motown-inspired tracks. It is important to note that most Motown songwriters did not perform as instrumentalists on their respective tracks. This specific practice-led

2 The audio engineering limitations of the 1960s are in comparison to the recording technology of today. Further, the recording technology utilised at Motown during the 1960s would have been considered cutting edge at the time. 
project is inspired by the work of Smokey Robinson, Stevie Wonder ${ }^{3}$ and Marvin Gaye-three individuals known for composing, producing and performing on their own releases.

Our goal with this album was to take on the role of a Funk Brothersinspired backing band and embrace some 1960s recording practices within the context of a new record production. This chapter is largely based on reflections of the recording of the rhythm section beds for Soul Sundays. My reflections are taken from various points of view to best investigate the Motown rhythm section. Throughout this chapter, I will refer to my research questions and aims from the perspective of the instrumentalist, the singer/songwriter and the producer.

\section{The Funk Brothers and Influential Members}

The Motown instrumentalists central to this research share origins with numerous African-Americans. Throughout the first half of the twentieth century, many of the Funk Brothers and their respective families migrated north from various Southern states to find employment and escape the segregation that affected every aspect of their daily lives. Lured by the thriving automotive industry and a chance for a better way of life, several instrumentalists who would later become regular session musicians at Motown found work on the assembly lines of Detroit's car factories. Nevertheless, musical ambition and stardom drove these individuals to chase after something more prestigious and profitable. Berry Gordy and his recording label provided them an alternative career path and opportunity to leave the car industry for good. However, the payment for a recording session at Hitsville USA was not a substantial increase to their previous factory wages. Between 1959 and 1960, it is documented that the Funk Brothers received a payment of US $\$ 5$ and a bowl of soup per session. ${ }^{4}$ Further, these recording artists were almost never acknowledged in the liner notes of record releases and were sternly prohibited from recording on their own or with any Motown rivals. ${ }^{5}$

3 By the 1970s, 'Wonder played most of the instruments on his albums, overdubbing drums, guitar, bass and keyboards' (DeCurtis, Henke and George-Warren, 1992, p. 298).

4 'Berry [Gordy] was gradually able to raise the pay scale of his studio musicians from the initial $\$ 5$ a side to $\$ 7.25, \$ 10, \$ 15$, and eventually several years later, the union scale of $\$ 52.50$ a session' (Slutsky, Jamerson and Gordy, 1989, p. 13).

5 It is important to note that this was common among other labels such as Chess and Sun Records. 
Hitsville USA was home to numerous session instrumentalists. However, Earl Van Dyke, William 'Benny' Benjamin and James Jamerson 'were the key men ... They were Motown's backbone, the men who played the music that made America dance' (George, 2003, p. 119). Aside from his performances on piano and organ, Van Dyke's roles as bandleader and 'studio organiser' (Lozito, 2001, p. 87) were equally essential to the productivity and direction of each recording session.

Regarding Benjamin's contribution, Slutsky (1998, p. 41) noted:

You need to hear only the intro to Martha \& the Vandellas' 'Dancing in the Street' to know where Benny Benjamin was coming from: energy and attitude. He also excelled at subtle kickdrum shadings, deft brush work, and the originality of his beats.

Slutsky also acknowledges Benjamin as the creator of the 'Motown drum beat': a rhythmic measure that features a constant quarter-note snaredrum pattern. This beat is regularly heard on Stevie Wonder's 'Uptight' (1965) and during the chorus section of The Temptations' 'Get Ready' (1965). Even though the bass drum pattern varies, the hi-hat and snaredrum patterns largely remain the same throughout the duration of these mentioned tracks. Benjamin's drumbeat quickly became a recurring theme in many other hit records and was adopted by all Motown drummers. From a drumming standpoint, I believe this drumbeat became an authentic rhythmic feature that allowed Motown to remain relatively distinctive among other soul labels. Tragically, Benjamin's personal flaw was his alcohol and drug dependence; in 1968, his self-abusive lifestyle led to his untimely death. Despite the passing of this influential artist, Motown was fortunate to have two other drummers able to deputise for Benjamin. Regarded by Slutsky as 'the master of the Motown shuffle', Richard 'Pistol' Allen provided drum arrangements on hit records such as The Four Tops' 1965 release 'I Can't Help Myself (Sugar Pie Honey Bunch)'.

The second-most prominent musician who carried on Benjamin's legacy was Uriel Jones - a drummer best known for his driving beat on the Marvin Gaye/Tammi Terrell duet 'Ain't No Mountain High Enough' (1967). During an interview for a magazine article, even Jones acknowledged Benny Benjamin as the most respected of the Motown drummers among the instrumentalists who recorded for this label. 
According to Jones:

Papa Zita [Benjamin's nickname] invented that Motown beat, and he taught it to us. Because of all his problems, we probably played drums on more Motown hits than he did. But he was Funk Brother \#1. (Slutsky, 1998, p. 41)

If Benjamin was the number one drummer, then James Jamerson was the most revered Motown bassist amid his peers. In simple terms, he was regarded as 'the player who everybody wanted on their sessions' (Lozito, 2001, p. 87). Respected musician and producer Don Was claims that Jamerson's bass contributions on Motown recordings are the height of creativity ... freedom and experimentation and fearlessness' (Justman, 2002). Probably the most remarkable feature of Jamerson's technique was that he performed all his bass parts with only his left hand and right index finger. According to his son, James Jamerson III, 'he played on all those hits with one finger. It was called the "hook"' (Justman, 2002). However, like Benjamin, Jamerson also sadly suffered from alcoholism. 'The ensuing deterioration of Jamerson's physical and mental health caused Motown to bring in Bob Babbitt to fill the void' (Slutsky, 1998, p. 41). His depression only intensified when the Motown recording company decided, without warning, to move its operations and headquarters to Los Angeles. His tragic death in 1983 was directly related to his alcoholism and depression. Despite the tragic endings to these musicians' lives, Benny Benjamin and James Jamerson are still regarded as the quintessential Motown rhythm section; understanding their musical partnership is integral in the creation of a Motown-inspired backing band.

\section{House Bands and Recording in the Shadows}

At this point in the article, it is very important to note that the Funk Brothers were certainly not the only prolific house band working in the US recording industry during the 1960s and 1970s. Further, it was common for record labels to not credit specific instrumentalists in the record liner notes. Consequently, their identities were often unknown to the public. It is clear that most US bands of this period rarely experienced any fame. Williams (2010, p. 59) commented: 
Popular music in particular supports a celebrity system centered on highly visible and easily identifiable individuals. Yet much popular music is in fact made by unknown, unidentified musicians, hired collaborators who work out of the public eye in the recording studio or in the shadows of the concert stage.

It is my opinion that today's recording artists should be aware of and celebrate the 'unidentified musicians' of the 1960s and 1970s for their respective recording contributions. They may not be considered stars (compared to lead vocalists) by the public; however, they should be remembered for performing the instrumental contributions that formed the foundation of most popular music tracks of this era. Exactly why the session musicians of this period remained largely uncelebrated and unknown is debatable.

On the west coast of the US, record producer Phil Spector made heavy use of a backing band known as the Wrecking Crew. Throughout the 1960s and early 1970s, this prolific backing band provided the rhythm section beds on hit records by The Beach Boys, Frank Sinatra, Nancy Sinatra, Sonny and Cher, Elvis, The Monkees and many more artists. Directed by the son of Wrecking Crew guitarist Tommy Tedesco, the 2014 documentary The Wrecking Crew provides an insight into the Los Angeles recording industry of the 1960s and 1970s, as well as interviews with many famous recording artists who had recorded with this relatively unidentified backing band. In the film, Brian Wilson describes this band as 'the focal point of the music' and the individuals 'with all the spirit and all the know-how especially for rock and roll music' (Tedesco, 2014). Nancy Sinatra also displays her admiration when she labels these instrumentalists as 'the unsung heroes of all those hit records'. However, there is also a general feeling of frustration conveyed by some of the film's interviewees, and this is evident later in the documentary when Mickey Dolenz (of The Monkees) notes:

The producers made a big mistake when they didn't put the credits on the back of their albums of all the people who had played on the albums. Not only did they deserve it, but I think it was misleading.

The conclusion I can draw from this documentary is that the Wrecking Crew-like their Detroit-based counterparts the Funk Brothers-were highly valued for their musical talents in the recording studio, but heavily underappreciated and unknown by the public. 
Thankfully, there is some valuable literature available that explores the role and importance of the session musicians that make up these 'house bands'. Zak III's The Poetics of Rock: Cutting Tracks, Making Records (2001) provides a scholar's perspective on the collaborative process of recording production. Zak III reflects:

Making records is intrinsically a collaborative creative process, involving the efforts of a 'composition team' whose members interact in various ways. As a matter of form, the 'artist' on a recording is usually the person or group who receives top billing on the album cover, but in fact most of the tasks involved in making a record require some measure of artistry. Social relationships among the team members also contribute to the outcome of a recording project. (p. 163)

Although this passage is found in the chapter entitled 'Engineers and Producers', I believe the 'composition team' to which Zak III refers to is a group of creative individuals that also includes session musicians. Campelo (2015) continues the theme of celebrating and highlighting the work of all who contribute to the music production process. As part of her concluding thoughts, this professional musician and scholar passionately proclaims:

It is my firm belief that session musicians should earn more credit for their anonymous work, on a general as well as an academic level. It would be important to clarify the type of contribution that these truly 'hidden musicians', using Ruth Finnegan's expression (Finnegan, 1989), gave to music cultures associated to popular music. (p. 7)

I agree with Campelo's comments regarding session musicians. Further, I believe all present and future music productions should accurately and honestly list all musical contributions in liner notes on each record. Irrespective of the payment for a performance, every individual who contributes to a popular music production — or any recording production for that matter-deserves to be credited for his or her respective involvement.

\section{Research Aims and Questions}

Following the work of Zak III and Campelo, this practice-led research project aims to highlight the contributions of 'hidden musicians'. In addition, a major goal of this project and research paper was to situate my proposed rhythm section in the 'shoes' of the Funk Brothers. 
As a 'compositional team', we wanted to investigate the mental, physical, emotional and musical pressures these session musicians endured during the production of Motown records. Time is one the most precious commodities in a recording session and it is my belief that the recording label in question was an expert in maximising its creative time. According to Motown's vibraphonist and tambourine player, Jack Ashford:

They [the Motown producers] would allow for four songs for a threehour session and we would get no less than two. But that's because the same group of guys played together all the time ... The only thing that changed was the changes. It was a home there. We spent so much time there. (Justman, 2002)

With this information in mind, it was my goal as the producer of Soul Sundays to record a minimum of two tracks per session.

Also, a primary ambition was to uncover the elements of Motown's live recording process that are applicable to modern record production. This style of recording is logistically more ambitious than the standard multitrack method that my collaborators and I are used to- this method generally involves recording each instrument separately. With this current recording project, I hoped to embrace the house band concept of recording a rhythm section bed as a full rhythm section.

Another major aim for this research was to create an ideal room for the recording of the live backing band that forms the foundation of the entire production. Throughout my undergraduate years, the topic of 'space' was often discussed in the context of acoustics and ambience. ${ }^{6}$ However, the subject of space in relation to the research at hand pertains to the other focus of ensemble unity. I believe the Motown basement recording room heavily influenced the interpersonal interactions between the session musicians. This confined work area may have presented numerous sonic challenges, but from a positive standpoint, it forced the band to work as united recording team. Again, it is important to note that the session musicians at Chess, Sun Records and Atlantic would have worked in similar recording spaces to their Motown counterparts.

For many of my collaborators, the idea of recording in the basement of a house is quite a foreign concept due to their previous experience of working in various commercial studios in South East Queensland.

6 See Doyle (2005) for a comprehensive analysis of the ambience used in twentieth century popular music productions. 
This choice of location may also be viewed as a budget option compared to recording in an existing, purpose-built facility. However, I intentionally chose the basement setting to better understand how this type of space influences the musical interactions between collaborators. I was particularly interested to explore how a basement studio affected my collaborators' individual performances during the recording sessions.

In preparation for the recording sessions, I aimed to source historically appropriate instruments and recording equipment. It intended to set up a completely analogue recording studio with instruments manufactured and assembled during the 1960s and 1970s. Following the work of Bennett (2012) and Bates (2012), I wanted to examine whether vintage instruments and equipment had any influence on our musical performance in the confines of our studio space.

Sourcing drums for this research was straightforward, as I already owned a collection of 1960s Ludwig drums in different dimensions and sizes. Glen Hunt (guitarist) was kind enough to lend his vintage Fender Precision Bass (the same bass make and model of Motown's James Jamerson and Bob Babbitt) to our bassist, Tim Hatch. A set of flatwound strings was purchased to complement the Fender P-Bass tone to recreate the bass tones of Jamerson. ${ }^{7}$ On the subject of keyboard sounds, we sourced a 1959 Hammond B-3 organ (which we amplified through a Leslie Cabinet), a 1970s Wurlitzer Electric Piano, a 1970s Rhodes Electric Piano Mark 1 and a 1967 Kawai upright piano. Finally, we hired a Tascam MS16 reelto-reel recorder as our recording device. From a historical perspective, this specific device was not historically appropriate due to its assembly in the 1980s. However, this specific model was selected because it was the most vintage multi-track tape machine available for hire. Also, from an audio engineering perspective, a major positive feature of this specific model was that it provided our production with 16 separate threads-we hoped this feature would make the mixing process easier. Overall, this obsession with sourcing vintage gear may be viewed as simply technostalgia. ${ }^{8}$ However, I believe that giving my collaborators the appropriate tools would aid our band to recreate the Funk Brothers' dynamic and sounds.

7 'An essential element of " "the Jamerson Sound" [was] heavy gauge Labella flatwound strings' (Slutsky et al., 1989, p. 85).

8 See Williams (2015) and Bennett (2012) for dissections of technostalgia. 


\section{Method}

Assembling an appropriate backing band for the Soul Sundays recording project was fortunately a simple task. First, I approached musicians that participated in my last research/recording project (Perry, 2012) and the subsequent Motown tribute show: Vincent Perry's Motown Revue. Three of my collaborators (Kevin Suierveld, Tim Hatch and Travis Lee) were my classmates during my undergraduate years and we had almost a decade of experience working together on various musical projects (see Table 6.1). Excepting Phil Mairu, every musician in my proposed personnel list was a current colleague of mine in one of the various function/corporate bands in South East Queensland. All members of the band regularly attended local jam nights and music social events as part of a group of musicians informally known as the Brisbane Jam Fam. We are all fans of Motown records and share a similar music vocabulary/repertoire.

Table 6.1: Years of mutual experience with my collaborators

\begin{tabular}{|l|l|l|}
\hline Artist name & Instrument/s & Years of mutual experience with me \\
\hline Kevin Suierveld & Congas & Nine \\
\hline Tim Hatch & Bass & Nine \\
\hline Travis Lee & Vocals & Ten \\
\hline Mitch Pattugalan & Piano and keyboards & Six \\
\hline Dan Wolsner & Piano and keyboards & Two \\
\hline Glen Hunt & Electric guitar & Three \\
\hline Xell Newton & Vocals & Three \\
\hline Brett Orr & Keyboards & Three \\
\hline Phil Mairu & Tambourine & None \\
\hline
\end{tabular}

Before we could arrange, record and produce an album of new tracks, our first job as an ensemble was to write new repertoire. Several members of the proposed backing band are respected singer/songwriter/producers in their own right. This meant that multiple members of the band acted as both songwriters and instrumentalists during the production of the album. Conveniently, Dan Wolsner and Brett Orr had previously written both the tracks that they were contributing to the album prior to the project-these four tracks were stylistically appropriate for the research. Travis Lee, Kevin Suierveld, Mitch Pattugalan and Xell Newton (collaborating with Tim Hatch, Glen Hunt and Chris Sheehy) all wrote new material specifically for the album (see Table 6.2). Between May 2014 
and April 2015, I organised arranging/jam sessions on various Sundays to work on the material. Sunday was the only day of the week when we could regularly meet and collaborate. This almost-weekly ritual became the inspiration for the album title: Soul Sundays. ${ }^{9}$

Table 6.2: Track listing, songwriting credits and record date details for Soul Sundays

\begin{tabular}{|l|l|l|l|l|}
\hline$\#$ & Song title & Songwriter/s & Vocalist & Record date \\
\hline 1 & 'We'll Get Together' & Dan Wolsner & Dan Wolsner & $15 / 05 / 15$ \\
\hline 2 & 'Just You and I' & $\begin{array}{l}\text { Travis Lee and } \\
\text { Kevin Suierveld }\end{array}$ & Travis Lee & $16 / 05 / 15$ \\
\hline 3 & 'Masterpiece' & Mitch Pattugalan & Mitch Pattugalan & $22 / 05 / 15$ \\
\hline 4 & 'Real Love' & Mitch Pattugalan & Mitch Pattugalan & $22 / 05 / 15$ \\
\hline 5 & $\begin{array}{l}\text { 'The Least That You } \\
\text { Can Do (Smile)' }\end{array}$ & Brett Orr & Brett Orr & $23 / 05 / 15$ \\
\hline 6 & 'Chemistry' & Brett Orr & Brett Orr & $24 / 05 / 15$ \\
\hline 7 & $\begin{array}{l}\text { 'Now You're Gone } \\
\text { (So Very Happy)' }\end{array}$ & $\begin{array}{l}\text { Xell Newton and } \\
\text { Glen Hunt }\end{array}$ & Xell Newton & $29 / 05 / 15$ \\
\hline 8 & 'Second Opinion' & $\begin{array}{l}\text { Xell Newton, Chris } \\
\text { Sheehy and Tim Hatch }\end{array}$ & Xell Newton & $29 / 05 / 15$ \\
\hline 9 & 'Change' & Dan Wolsner & Dan Wolsner & $30 / 05 / 15$ \\
\hline 10 & 'Always' & $\begin{array}{l}\text { Travis Lee and } \\
\text { Kevin Suierveld }\end{array}$ & Travis Lee & $30 / 05 / 15$ \\
\hline
\end{tabular}

During the arranging and preproduction process, we carefully listened to and analysed iconic Motown records (on vinyl when possible) for directions on instrumentation, songwriting elements and audio production components. The Supremes A' Go-Go (1966), The Motown Story (Volume One) (1971), What's Going On (1971) and Stevie Wonder's Songs in the Key of Life (1976) became essential listening as I acquired each album on LP. To properly analyse the sonic texture of these records, I made a conscious decision to avoid listening to any MP3 or remastered versions of these Motown releases. Further, when possible, we tried to source vintage instruments to replicate sounds and textures heard on Motown releases.

9 See Thompson and Lashua (2014) for other studio-based ethnographic research. 


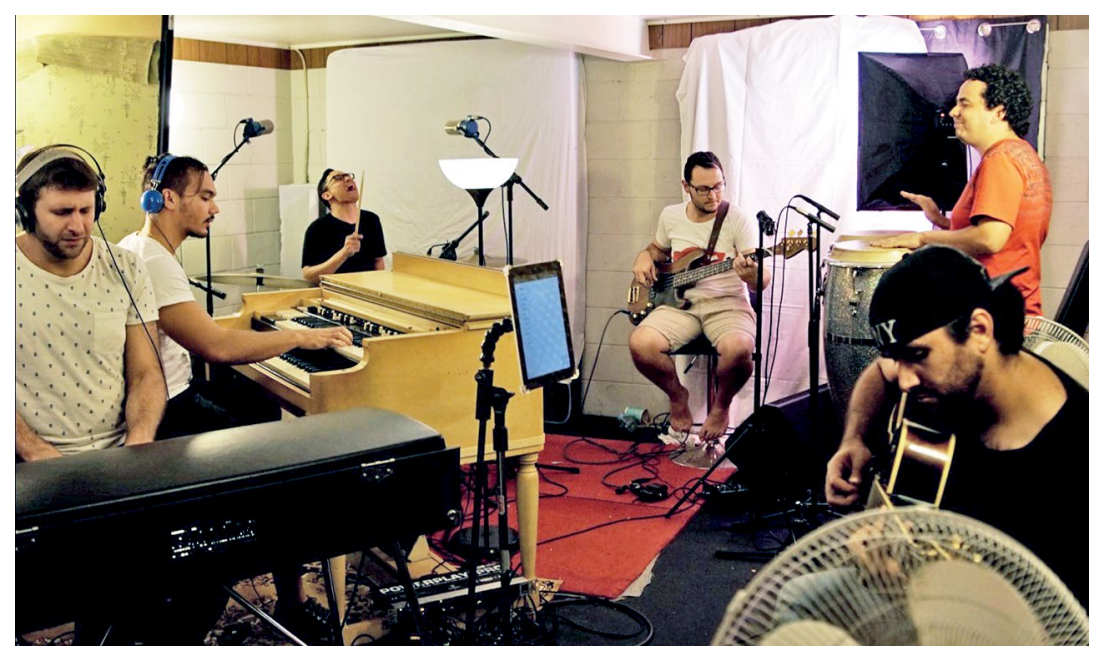

Figure 6.1: Our backing band recording in the temporary basement recording studio: (from left to right) Dan Wolsner, Mitch Pattugalan, Vincent Perry, Tim Hatch, Glen Hunt and Kevin Suierveld

Source: Perry (2012).

Next, we installed a temporary recording space/studio in the basement of a suburban house. Band members Tim Hatch and Xell Newton were kind enough to volunteer their home in Salisbury for the preproduction process (writing and arranging) and their subsequent house in Mansfield ${ }^{10}$ for the recording of rhythm section beds. As discussed in the section covering the research questions, we had previous experience recording together in a large-format recording studio. ${ }^{11}$ After that album production, I understood that a large recording room with tall ceilings was not ideal when trying to replicate the Motown sound. Further, it was my theory that if we could record in a basement, we might be able to replicate the sonic characteristics of Motown's recording room.

Between 15 and 30 May 2015, we recorded all the rhythm section beds for the 10 proposed tracks. When possible, we tracked each song with the entire rhythm section present. Colleague and former classmate James Fox Higgins was hired as audio engineer. During the recording sessions, he was in the control booth in the adjoining room. His main role on the first day of recording was to help set up microphones in appropriate locations,

10 Salisbury and Mansfield are suburbs of Brisbane.

11 Studio A and room 1 at the Queensland Conservatorium's Gold Coast campus (Griffith University) were used during the previous research project (Perry, 2012). 
assign channel volume levels via an analogue console and operate the 16-channel tape machine he had hired to our band for the project. After the first day of recording, everything was left in place for the following two weeks so we could simply return to the studio, turn on the appropriate equipment and carry on where we had left off.

I purchased a 1-in reel of analogue tape to record in conjunction with James's Tascam MS16 reel-to-reel recorder. We limited our number of takes for each song based on the duration of the reel. In most cases, we achieved a maximum of eight takes on each reel (for the shorter songs). After we recorded a take that all rhythm section instrumentalists were satisfied with, we recorded/transferred all passes of each song to Pro Tools 10 (my preferred digital audio workstation) via two 8-channel Focusrite Sapphire Pro40 interfaces. I chose to transfer these recordings to Pro Tools, as we only had access to the reel-to-reel recorder during these first three weekends of the production. Further, I planned to record a series of overdubs (vocals, strings, brass and percussion tracks) over the coming months in various different recording studios. My laptop and Pro Tools software allowed me to easily edit, comp ${ }^{12}$ and transfer audio data without the usage and transportation of a reel-to-reel recorder.

As there was only one tape reel, we erased the tape after each track to record the next song. This recording limitation promoted a sense of finalisation after each track and clearly motivated a higher level of musical performance among my collaborators. As part of documenting the creative process and work environment, I hired filmmaker Mason Hoffman and his assistants to film all recording sessions. The video footage captured was very valuable when I began to reflect on the rhythm section recording process.

\section{Results, Outcomes and Reflections}

Recording one song can be a very time-consuming process. Originally, I booked in the band and hired the recording gear for two weekends (four sessions in total) with the goal of recording the 10 proposed tracks. In hindsight, this was not nearly enough time. It ended up taking seven separate sessions over three weeks to record all the rhythm section beds. Also, I did not allocate sufficient time to set up the immense amount of recording and musical gear in our basement studio. Further, we were only

12 See Senior (2011) for a definition and explanation of the process of audio comping. 
able to track one song on the first day because I underestimated the time taken to sound check microphone levels and ensure everyone had quality headphone monitoring. My poor time management heavily affected my creativity and drumming performance. On more than one occasion, I was more concerned with keeping up with my unrealistic recording schedule than worrying about the quality of the actual tracks. This time pressure also affected my individual mood, which affected my fellow recording artists and their respective performances. On a positive note, productivity did improve over the three weekends because we naturally became more comfortable in the surroundings of the basement studio. Our ensemble dynamic noticeably improved during this challenging process and each completed track developed our confidence as a band.

Tracking live as a band is challenging for all those involved. This specific process requires a group of multiple musicians to record together-often in a single space-to achieve a collective goal. It is frequently stressful, tiring and occasionally intimidating being in the presence of peers. Also, there is a small margin of error when recording whole rhythm section beds. Each musician relies on each other to execute his or her respective parts and the pressure of not disappointing your fellow band mates can often create a deep sense of anxiety and internal pressure. However, when our band was able to record a full take, it felt like a genuine achievement and a true team effort. When we played back each take, we could hear how individual performances were combined to create a unified music recording; personal anxiety and stress were now replaced with collective relief and euphoria.

It occurred to me on the second day of the recording project that the anxiety regarding my individual performance should be replaced with encouraging thoughts and positive energy. Instead of worrying about making mistakes, I was motivated to inspire the musicians around me by performing to the best of my ability and laying down a solid drum part on every take. Further, I eventually discovered that my positive energy and presence were more valuable than a solid drum performance. The simple act of smiling and demonstrating that I was enjoying the experience (of working with the group) benefited those around me in the room. We were much more efficient as an ensemble when we were having fun and our respective body language influenced the collective mood in the room. Brett Orr reflected on the recording process and noted, 'When you're looking up at Tim [band bassist] and he's just grinning his arse off, as opposed to someone who is just staring at a chart-it's a big difference' 
(personal communication, 16 January 2016). Brett's reflection reminded me of the importance of sharing positive emotion with your fellow instrumentalists. I believe that Tim's simple act of smiling improved the collective mood of the studio and it acknowledged that he was enjoying sharing that moment working as an ensemble.

The other major benefit of recording as an ensemble was that we were forced to listen to each other's parts in relation to our own individual part. I believe that the chordal players-Glen (electric guitar), Mitch (keyboards) and Dan (keyboards) - benefited from recording together because they often wrote and arranged their respective parts at the same time during each take. This trial-and-error style of arranging would occasionally result in one or more musicians spoiling a quality take. However, if a musical idea (such as a keyboard lick or riff) was too complicated, dissonant or unfitting for the song, we instantly knew based on body language and hearing each other. Conceptually, recording each song was similar to a group of people assembling a jigsaw puzzle together.

Further, there were feelings of finalisation after each take because we knew we were recording to tape as a band. It was quite liberating to commit to a part and not be concerned about performance errors that needed to be repaired in the post-production phase. This style of recording promoted better ownership of our performance-both individually and collectively as an ensemble. Also, by tracking together, we saved the time normally allocated to tracking each instrument individually. Instead of organising a full day to record guitar or piano parts, we dedicated time to recording a complete rhythm section bed.

The experiment of working in a temporary basement recording studio/ room provided an encouraging and welcoming space for creative work and it 'didn't feel like there was any financial/time pressure' during the sessions (Brett Orr, personal communication, 16 January 2016). Financially, this project was a fairly affordable venture. Conversely, large-format recording studios are expensive to hire and don't always provide a space in which musicians can feel comfortable or creative. Considering the decline of profits in the recording industry over the past 15 years, ${ }^{13}$ this method of home recording presents a sustainable and affordable option for producers (such as myself) to efficiently record full ensembles on a regular basis.

13 'Over the past 15 years, there has been a decline in large corporate owned studios and a rise in smaller independently owned, producer-based studios. Many of these studios are in private homes, owned by a mixture of hobbyists and professionals. Here, producers own and operate their own studio, often functioning as both a sound engineer and musician' (O'Grady, 2014, p. 103). 


\section{Concluding Thoughts}

It is difficult to comprehend the pressures and challenges experienced by the Funk Brothers (or other notable house bands) throughout the 1960s and 1970s. However, after forming a backing band modelled on the Funk Brothers and recording an album of Motown-inspired original songs, I have a greater understanding of the interpersonal skills required to be an efficient rhythm section. Also, this practice-led research demonstrated the level of musicianship required to record rhythm section beds as a full ensemble-something that I had only read about in scholarly work and viewed in documentaries.

Further, recording songs as a complete rhythm section is often a stressful process and allows for a very small margin of error. However, when successfully conducted, this recording method can produce tracks that promote ensemble unity. Also, I believe that the individual instrumentalists involved will mature as recording artists and hone various skills that are valuable to session musicians. During the production of Soul Sundays, I observed how my fellow musicians have become more time efficient and technically proficient on his or her respective instruments. This is partly due to the nature of recording together as a section and not individually. While performing my responsibilities as band drummer and musical director, I have witnessed an improvement in my own skills-most notably in my ability to communicate with my peers. I have developed a greater appreciation of both verbal and non-verbal communication in the recording studio. Also, this research has highlighted the importance of band diplomacy. Working in an ensemble requires a group of instrumentalists to respect and trust one another to achieve collective success.

Regarding house bands, the recording community and industry need to applaud and properly credit the contributions of these hidden musicians. The public may only idolise and glorify the performances of vocalists who are the face of a track; however, everyone involved in the compositional team deserves to be celebrated and, at the very least, listed on the liner notes of a record. Stardom may be anointed to a select few; nevertheless, all those who have contributed to a recording should share credit.

The most positive outcome from this research project was the completion of 10 rhythm section beds-the foundation and backbone of 10 original Motown-inspired tracks. Also, each keyboardist who appeared on the 
album had the opportunity to appear as a lead vocalist on his or her respective tracks. With the release of this album in mid-2017, I am fully aware that there is no guarantee of commercial success and stardom for any of the singer/songwriters. However, this collaborative recording process and study of backing bands of the past has taught me to value and recognise every individual who contributed to the completion of Soul Sundays. Finally, it is my hope that many of the revelations and findings of this production will aid me in my future recording projects and research.

\section{References}

Bates, E. 2012. 'What Studios Do'. Journal on the Art of Record Production 7.

Bennett, S. 2012. 'Endless Analogue: Situating Vintage Technologies in the Contemporary Recording \& Production Workplace'. Journal on the Art of Record Production 7: 1-18.

Borthwick, S. and R. Moy. 2004. Popular Music Genres. Edinburgh: Edinburgh University Press Ltd.

Campelo, I. 2015. 'That Extra Thing-The Role of Session Musicians in the Recording Industry'. Journal on the Art of Record Production 10.

Covach, J. and A. Flory. 2012. What's That Sound?: An Introduction to Rock and its History (3rd ed.). New York: Norton.

DeCurtis, A., J. Henke and H. George-Warren. 1992. 'Stevie Wonder'. In The Rolling Stone Illustrated History of Rock \& Roll, edited by J. Miller. London: Plexus Publishing Ltd.

Doyle, P. 2005. Echo and Reverb: Fabricating Space in Popular Music Recording, 1900-1960. Middletown: Wesleyan University Press.

Emerson, K. 2005. Always Magic in the Air: The Bomp and Brilliance of the Brill Building Era. New York: Viking.

Finnegan, R. 1989. The Hidden Musicians: Music-Making in an English Town. Cambridge: Cambridge University Press.

George, N. 2003. Where Did Our Love Go? The Rise \& Fall of the Motown Sound. London: Omnibus Press (A Division of Music Sales Limited). 
Justman, P. (Director). 2002. Standing in the Shadows of Motown. Santa Monica, California: Artisan Entertainment.

Lozito, C. 2001. 'Sons of the Snakepit'. In Calling Out Around the World: A Motown Reader, edited by K. Abbot. London: Helter Skelter Publishing.

Moorefield, V. 2005. The Producer as Composer: Shaping the Sounds of Popular Music. Cambridge: MIT Press.

O'Grady, P. 2014. 'Studio Hubs: Changing Recording Environments'. In Communities, Places, Ecologies: Proceedings of the 2013 IASPM-ANZ Conference, edited by J. O'Regan and T. Wren, 103-11. Brisbane: International Association for the Study of Popular Music, Australia and New Zealand Branch.

Perry, V. 2012. In Search of Soul and Groove: A Study of the Motown Drum Sound. Queensland Conservatorium, Griffith University.

Senior, M. 2011. 'Comping: Reaper Tips \& Techniques'. soundonsound. com/techniques/comping (accessed 20 October 2016).

Slutsky, A. 1998. 'United We Stand: James Jamerson and Benny Benjamin'. Bass Player 9: 40-41.

Slutsky, A., J. Jamerson and B. Gordy. 1989. Standing in the Shadows of Motown: The Life and Music of Legendary Bassist James Jamerson. Wynnewood: Hal Leonard.

Tedesco, D. (Director). 2014. The Wrecking Crew. C. Hope, J. Leonoudakis, M. Linden, C. Scanlon, D. Tedesco and S. G. Tedesco (Producers): Madman Entertainment Pty Ltd.

Thompson, P. and B. Lashua. 2014. 'Getting it on Record: Issues and Strategies for Ethnographic Practice in Recording Studios'. Journal of Contemporary Ethnography 43 (3): 746-769. doi.org/ $10.1177 / 0891241614530158$

Williams, A. 2010. 'Navigating Proximities: The Creative Identity of the Hired Musician'. Journal of the Music \& Entertainment Industry Educators Association 10 (1): 59-76.

—_. 2015. 'Technostalgia and the Cry of the Lonely Recordist'. Journal on the Art of Record Production 9. 
Zak III, A. J. 2001. The Poetics of Rock: Cutting Tracks, Making Records. London: University of California Press. doi.org/10.1525/ california/9780520218093.001.0001

\section{Discography}

Ashford, N. and V. Simpson. 1967. 'Ain't No Mountain High Enough'. Tamla Motown.

Gaye, M. 1971. What's Going On. Motown Record Corporation.

Gordy, B. 1971. The Motown Story: Volume One. Motown Record Corporation.

Holland, B., L. Dozier and E. Holland. 1966. The Supremes A' Go-Go. Tamla Motown.

Robinson, S. 1965. 'Get Ready'. Gettin' Ready. Tamla Motown.

Wonder, S. 1976. Songs in the Key of Life. Motown Record Corporation.

Wonder, S., S. Moy and H. Cosby. 1965. 'Uptight (Everything's Alright)'. Tamla Motown. 
This text is taken from Popular Music, Stars and Stardom, edited by Stephen Loy, Julie Rickwood and Samantha Bennett, published 2018 by ANU Press, The Australian National University, Canberra, Australia.

doi.org/10.22459/PMSS.06.2018.06 